\title{
Ri-configurazione di parti ed elementi dell'architettura rurale: il recinto, la corte e la torre del Yue jiazhuang nel Fujian in Cina
}

\author{
Antonio Conte \\ Marianna Calia \\ Roberto Pedone \\ Anna Lovino \\ Mara Manicone \\ Francesca Sbano
}

Abstract

Al di là delle megalopoli, dell'alta tecnologia che ha invaso le comunità locali, esiste una Cina fatta di architetture immerse nel verde delle grandi risaie, delle alte montagne e degli estesi boschi di bambù. Una Cina agricola fatta di uomini che trasportano enormi ceste di ortaggi su stretti camminamenti in terra battuta, che conservano gli usi e i costumi che da secoli si tramandano come rituali di modi di vita e di adattamento alla terra.

In questo contesto si colloca il lavoro di ricerca presentato, in continuità con il viaggio studio compiuto a marzo 2019, co-finanziato dal bando MAECl scambi giovanili, che ha permesso di approfondire la conoscenza e lo studio di fortificazioni in terra cruda proprie della regione del Fujian.

Tulou, tubao e zhuangzhai: tre tipologie di insediamenti abitativi con caratteri comuni, ognuna con una propria storia ed una tradizione costruttiva da indagare e raccontare. I sopralluoghi a cinque zhuangzhai collocati nella contea di Yongtai, ci hanno condotto alla scelta del caso studio: lo Yue jiazhuang. La sperimentazione progettuale si è concentrata sulla conoscenza, interpretazione, ricostruzione e ripristino di alcune parti in rovina ed alcune totalmente demolite, avvalendosi di strumenti e metodi del rilevamento architettonico, anche mediante tecnologie avanzate digital3D e droni, della composizione architettonica, del restauro e della rigenerazione urbana.

Parole chiave

paesaggi rurali, architettura fortificata, intreccio, ri-abitare, zhuangzhai.

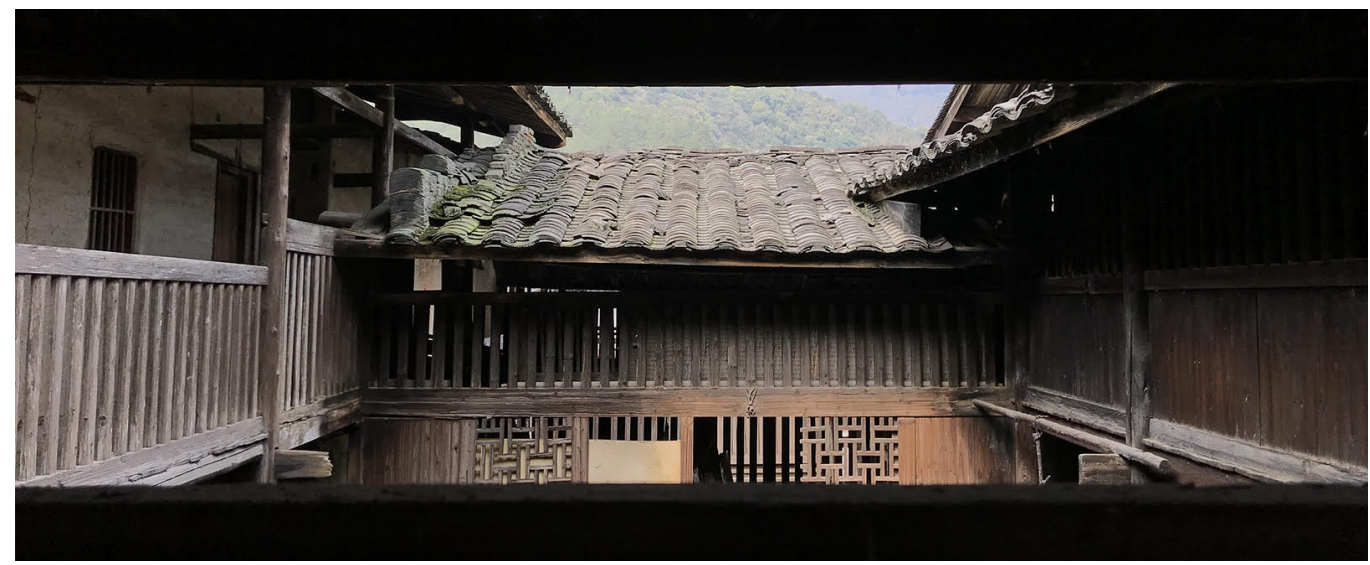




\section{Disegnare, pensare, costruire in paesaggi lontani}

"Non ho scritto neppure la metà delle cose che ho visto" [Marco Polo, II Milione, 20I I, p. 48]

Così scrive Marco Polo, il grande viaggiatore che per primo ha diffuso in Occidente scritti e racconti dettagliati sulla Terra di Mezzo. Tante etnie, lingue, volti, costumi e culture: la Cina è questo e altro ancora. Unico impero millenario nella storia dell'umanità, un tempo chiuso e autoreferenziale, in questi ultimi decenni si trova al centro di una notevole accelerazione evolutiva in tutti i campi dell'umano. Ma al di là delle megalopoli, dell'alta tecnologia che ha invaso le comunità locali, esiste una Cina fatta di architetture immerse nel verde delle grandi risaie, delle alte montagne e degli estesi boschi di bambù. In questo contesto si colloca la ricerca presentata, in continuità con il viaggio studio compiuto a marzo 2019 , che ha permesso di approfondire la conoscenza delle fortificazioni in terra battuta, proprie della regione del Fujian, concentrando l'attenzione sul progetto di nuovi modi di 'abitare la terra'. Tulou, tubao e zhuangzhai: tre tipologie di insediamenti con caratteri comuni, ognuna con una propria storia e una tradizione costruttiva da indagare e descrivere. Se i tulou, ormai iscritti nella lista UNESCO dal 2008, hanno già raccontato le loro storie, tubao e zhuangzhai restano ancora poco indagati. Questa ricerca e sperimentazione progettuale, si è sostanziata con la partecipazione al workshop co-finanziato dal MAECl per il bando "Scambi Giovanili" [I]. Il progetto si articola attraverso la descrizione di un percorso di conoscenza ampio, dalle Dinastie che hanno governato il Paese, agli approfondimenti sull'architettura cinese tradizionale e rurale, per concentrarsi sui zhuangzhai della regione del Fujian. II lavoro di ricerca si è sviluppato, non solo sui principi costruttivi dell'architettura cinese, ma anche sulle profonde influenze che simboli, credenze e filosofie hanno avuto su di essa, dai precetti dell'architettura del feng shui alle sue tipologie, fino agli approfondimenti su parti ed elementi costruttivi dell'architettura fortificata in terra cruda.

I sopralluoghi a cinque zhuangzhai collocati nella contea di Yongtai, hanno condotto alla scelta del caso studio: lo Yue jiazhuang. La sperimentazione progettuale si è concentrata sulla conoscenza, interpretazione, ricostruzione e ripristino di alcune parti in rovina e altre demolite, avvalendosi di strumenti e metodi del rilevamento architettonico, anche mediante tecnologie avanzate digital3D e droni. Conoscenza e Progetto si sono spesso sovrapposti

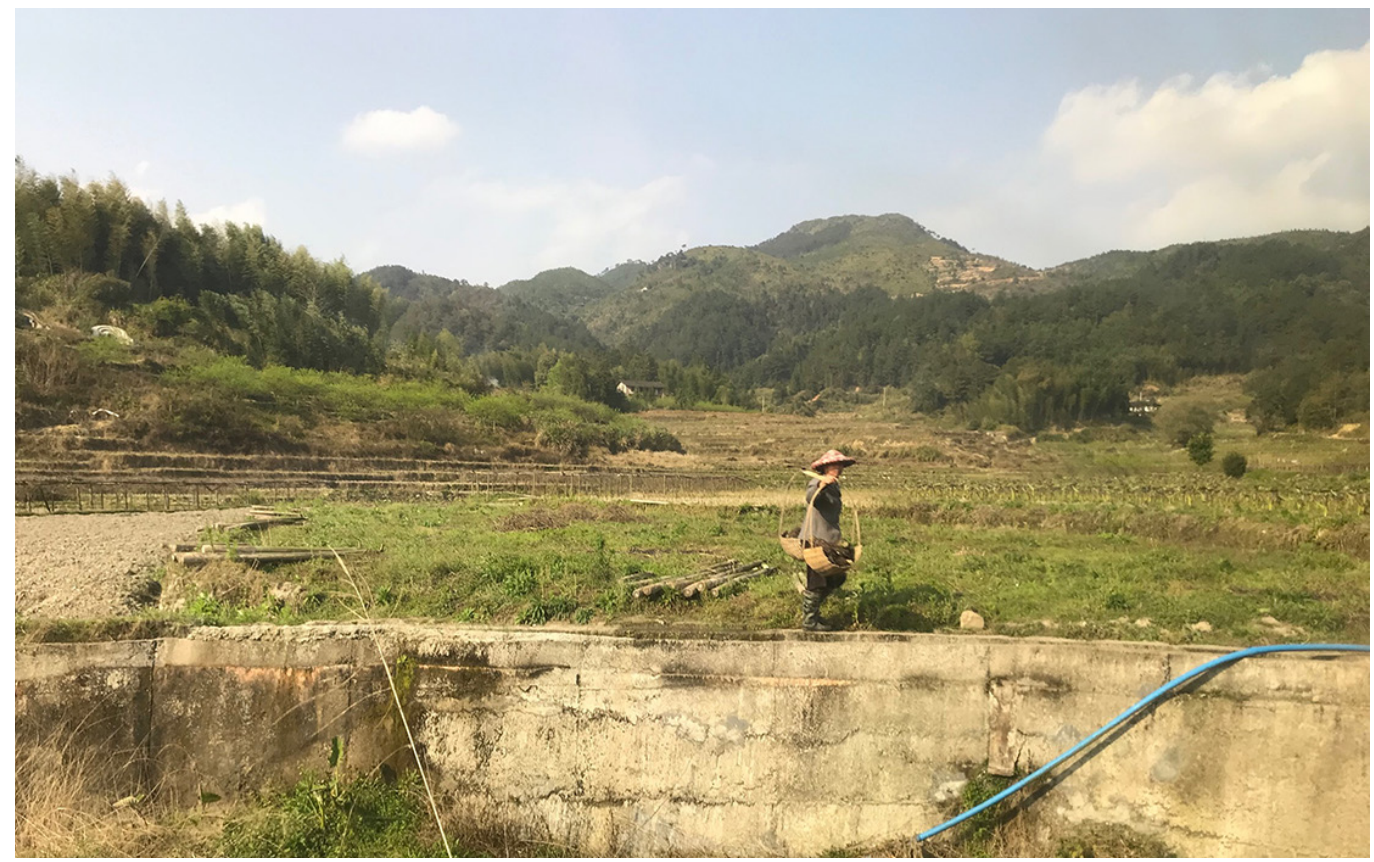


nel rispetto della tradizione locale, tra l'approccio culturale della nostra formazione e quello di tipi e modelli condiviso nella storia complessa dei modi di abitare la Terra, che hanno attraversato culture profondamente diverse. Comprendere gli archetipi, i tipi e le forme, le parti e gli elementi, le necessità umane dei residenti e del territorio e tradurle in architettura, si è trasformato in disegni interpretativi di un modo di vivere che rappresenta una realtà complessa ancora da approfondire, valorizzare e testimoniare. II progetto, tra analisi e rappresentazione, ha tentato di dare alcune risposte per una concreta ipotesi di trasformazione. In questo nostro percorso di comprensione e appropriazione di culture profondamente diverse, disegnare, pensare e costruire in paesaggi lontani, rappresenta compiutamente attraverso il progetto, una testimonianza di continuità di opere collettive di un'antica tradizione nel ri-abitare la Terra. (A.C.).

\section{Strumenti e metodi di ricerca per la conoscenza di antichi patrimoni nel Fujian}

$$
\begin{array}{r}
\text { "Costruisci meglio che puoi. Ma non oltre le tue possibilità. } \\
\text { [...] Fa' attenzione alle forme con cui costruisce il contadino, perché sono patrimonio tramandato della } \\
\text { saggezza dei padri. Cerca però di scoprire le ragioni che hanno portato a quella forma. } \\
\text { t...] Non temere di essere considerato poco moderno. I cambiamenti delle tecniche costruttive } \\
\text { tradizionali sono ammissibili solo quando comportano dei miglioramenti; } \\
\text { in caso contrario, mantieniti ancorato alla tradizione. } \\
\text { Perché la verità, anche se vecchia di centinaia di anni, } \\
\text { ha con noi un legame interno più forte della menzogna che ci cammina accanto" } \\
\text { [Loos Adolf, Parole nel vuoto, I 992 p. 27I] }
\end{array}
$$

L'approccio alla conoscenza di luoghi lontani con caratteri profondamente diversi da quelli cui siamo abituati a confrontarci ogni giorno, può spaventare ma anche affascinare a tal punto da spingere un gruppo di studenti e ricercatori lucani, a sviluppare un progetto di ricerca e sperimentazione progettuale, complesso e articolato.

Le relazioni internazionali dell'Università degli Studi della Basilicata con la Cina, faticosamente costruite con passione e determinazione dal 2009, hanno trovato nella Fuzhou University un partner decisivo e disponibile a condividere linee di ricerca intorno a temi di tutela e valorizzazione dei patrimoni architettonici e paesaggistici. L'interesse per i sistemi di 'architetture di terra', costruiti sapientemente nel corso dei secoli attraverso il consolidarsi di tradizioni costruttive, uso dei materiali locali e composizione degli spazi, è maturato grazie al supporto dei colleghi della FZU e agli intensi sopralluoghi di studio e rilievo condotti.

I zhuangzhai appartengono ad una delle tipologie di architettura fortificata rilevate nelle estese zone rurali della regione del Fujian, costa sud orientale della Cina. La scelta di approfondirne i caratteri e l'identità, è motivata dalla carenza di informazioni e studi di valenza scientifica su di essi.

Allinterno della classificazione ampia di 'architetture in terra del Fujian', si possono menzionare, inoltre, i tulou, grandi residenze collettive con chiari caratteri simbolici, i tubao, rifugi fortificati temporanei, che rappresentano il tentativo dell'uomo di costruire in stretta relazione con la morfologia del terreno e i weilongwu veri e propri aggregati abitativi seriali, edificati dalle etnie Hakka prevalentemente nella regione del Guangdong.

A fronte di un'attenta attività di conoscenza e avvicinamento alla cultura millenaria cinese attraverso gli strumenti propri dell'Architettura, sostanziati con restituzioni di rilievi svolti in loco e disegni di sintesi analitica, questo lavoro ha tradotto meticolosamente e criticamente in pensiero progettuale un lavoro condiviso con docenti e ricercatori dei due Paesi, coinvolti nelle diverse fasi di sopralluogo in situ e di laboratorio progettuale e sperimentazione didattica.

L'obiettivo che questo lavoro si propone, è connettere e promuovere la conoscenza di queste architetture di terra all'interno della comunità scientifica internazionale, fornendo un contributo personale e critico alla loro tutela e rigenerazione sostenibile contemporanea, anche a sostegno di una possibile partecipazione alla candidatura dei zhuangzhai a patrimonio dell'Umanità. (M.C.). 


\section{L'osservazione, fenomeno critico della prefigurazione alla nuova forma}

Indagare una struttura così complessa attraverso il riconoscimento della sua modularità, della composizione delle parti, degli intrecci e degli incastri, ha richiesto un approccio visivo diretto e descrittivo incessante.

Il zhuangzhai è un edificio rurale dal grande valore paesaggistico, il cui forte legame con la terra si evidenzia dove i suoi abitanti partecipano intimamente ai cicli di raccolto. Si leggono tracce dei miti tra religione e cultura costruttiva locale, attraverso la partizione razionale degli ambienti, il cerchio, l'astrazione della volta celeste e il quadrato, il basamento l'attacco a terra e alla vita terrena, tutto si fonde restituendo un'aurea di sacralità leggibile nelle pitture nere su sfondo rosso che ricoprono i supporti lignei della corte centrale.

Negli incastri delle strutture lignee si annodano saperi lontani e tecnica manualistica, attraverso gli innesti orizzontali e verticali e i terminali poggiati su blocchi di pietra sagomati e intagliati con disegni geometrici ripetuti. In questo dettaglio ritroviamo una delle regole principali delle costruzioni, il rapporto tra acqua ed edifico: staccare il supporto ligneo dal terreno per evitare l'adescamento dell'acqua ed il suo lento e inesorabile deterioramento. $\grave{E}$ evidente come la sintesi architettonica, abbia risposto a questo problema in duplice modo: istanza tecnica ed istanza estetica in soluzioni originali finemente eseguite.

In questa cornice di considerazioni si percorre una delle strade possibili: la volontà di restituire l'aspetto fondativo dell'edificio che è stato privato di parti testimoniali importanti come la torre d'angolo, il fronte di ingresso e la chiusura retrostante. La scelta ordinatrice dell'intervento è stata la ricomposizione integrale dell'immagine del zhuangzhai, avvenuta tramite lo studio delle lacune architettoniche con lo scopo di ridare unità all'organismo. Individuati gli obiettivi del progetto sperimentale, la ricostruzione è avvenuta modulando un materiale locale sostenibile come il bambù, attraverso la giustapposizione di elementi disegnati in dettaglio e messi in relazione con il contesto. (R.P.).
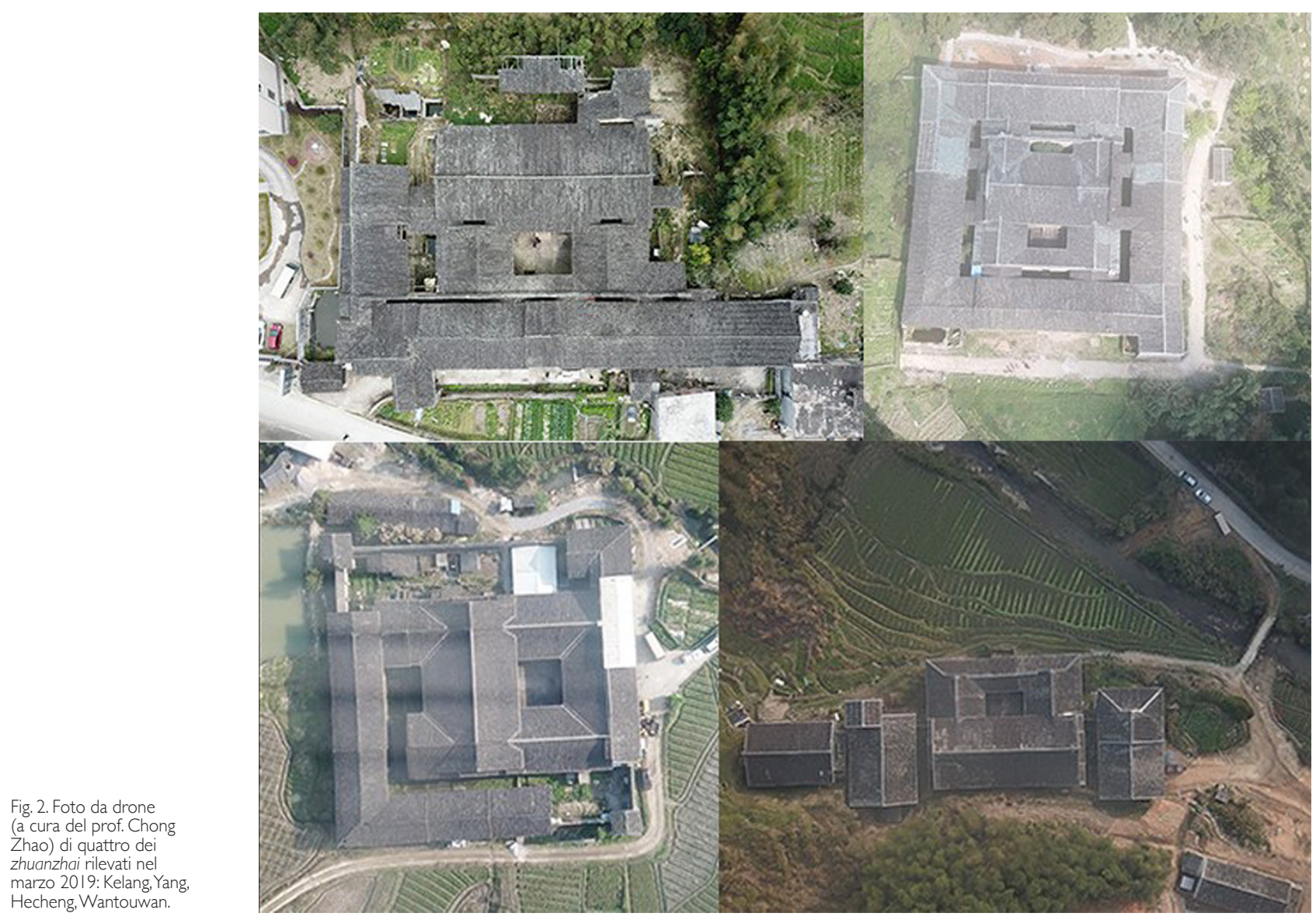


\section{II recinto: ricostruzione e reinterpretazione sulle tracce del fronte demolito}

Nel 1970 nel villaggio di Ling Xiao esigenze pratiche e politiche, prevalendo su quelle culturali ed estetiche, hanno causato modifiche sostanziali al contesto rurale e all'immagine unitaria del Yue jiazhuang. Demolendo il fronte principale e una delle torri d'angolo, si è rinunciato all'integrità del manufatto, compromettendone l'aspetto e rinunciando ai principi geometrici di simmetria. Ciò che rimane è un'architettura incompleta e vulnerabile, che necessita di un nuovo volto per relazionare natura e costruito.

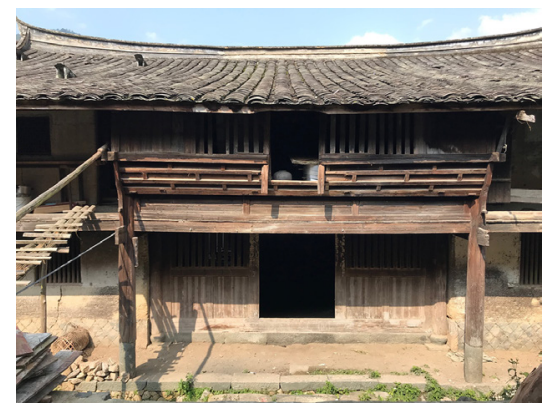

La soluzione è stata evidenziata dallo stesso contesto e dalle fitte piantagioni di bambù che hanno ispirato l'idea di infondere la stessa scansione modulare in un ritmo architettonico. Alternanza tra pieno e vuoto, che avvicina alla spazialità più densa di materia, propria dell'interno della fortificazione. Lo spazio architettonico diviene narrazione storica, capace di lasciar trasparire miti, tradizioni e solidità costruttiva, lasciando al contempo traccia di ciò che era. II progetto intende completare l'edificio nella forma proponendo un'integrazione della lacuna, che si misura con l'ambiente circostante e ne ripropone la modularità. Questa regola empirica, leggibile dalla maglia dedotta dai setti e dalle aperture dell'edificio, ha consentito di trovare la distribuzione interna del progetto e ha determinato la posizione dei pilastri in bambù del prospetto articolato su tre livelli: il piano terra è uno spazio simbolico caratterizzato dalla verticalità dei pilastri. Le ombre disegnano in orizzontale ciò che la materia esprime in verticale, conducono verso gli imponenti portali, indirizzando lo sguardo verso il colore caldo delle pareti in terra cruda con le tracce delle demolizioni. II primo e il secondo piano sono luoghi narrativi, museo in divenire che esalta la pittura e la calligrafia nel luogo più riservato dell'edificio: la torre.

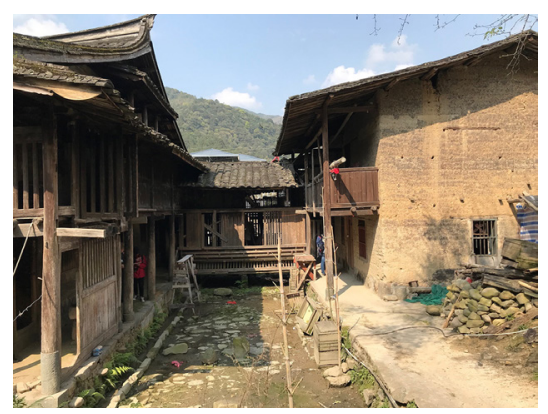

La suggestione è accentuata dall'affaccio sul paesaggio, nuovo punto d'osservazione dal quale scorgere il villaggio nella sua interezza, un dettaglio che rappresenta la "porta del monumento'. Lo spazio da cui è possibile apprezzare i caratteri dell'intero zhuangzhai è il secondo piano, un ambiente che richiama lo spazio ristretto del sottotetto degli edifici rurali, scandito dai pilastri che reggono la copertura e da schermature fitte che ritagliano lo scenario in suggestive inquadrature. La cornice di questa figurazione è l'imponente copertura in bambù, che reinterpreta, sovrasta e protegge la domesticità ritrovata. (A.L.). 
Fig. 5. Confronto tra la foto da drone dello stat di fatto e il disegno di

progetto di ricomposizio-

ne del fronte demolito $e$

risistemazione dell'area
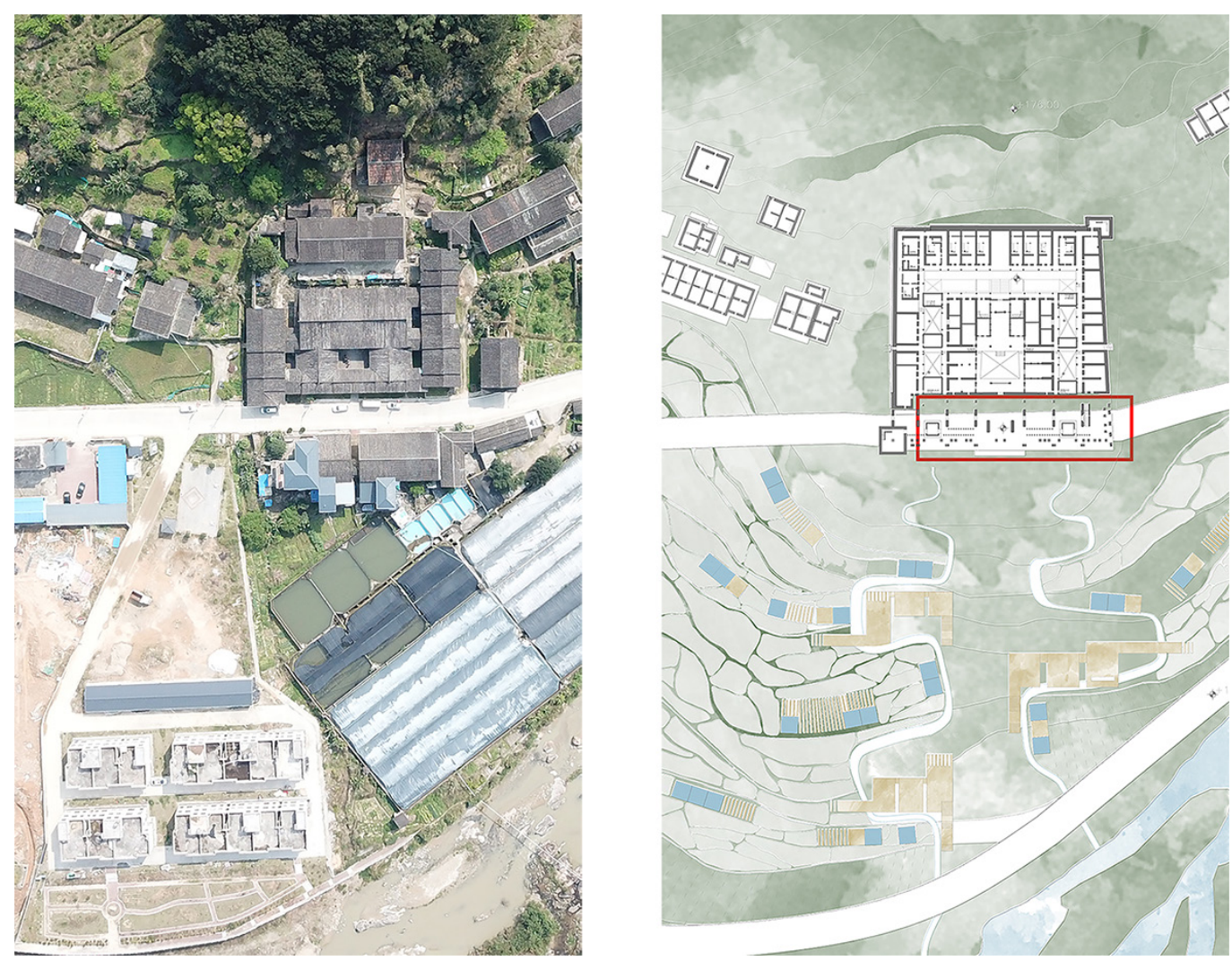

Fig. 6. Prospetto del fronte principale riprogettato delYue jiazhuang.

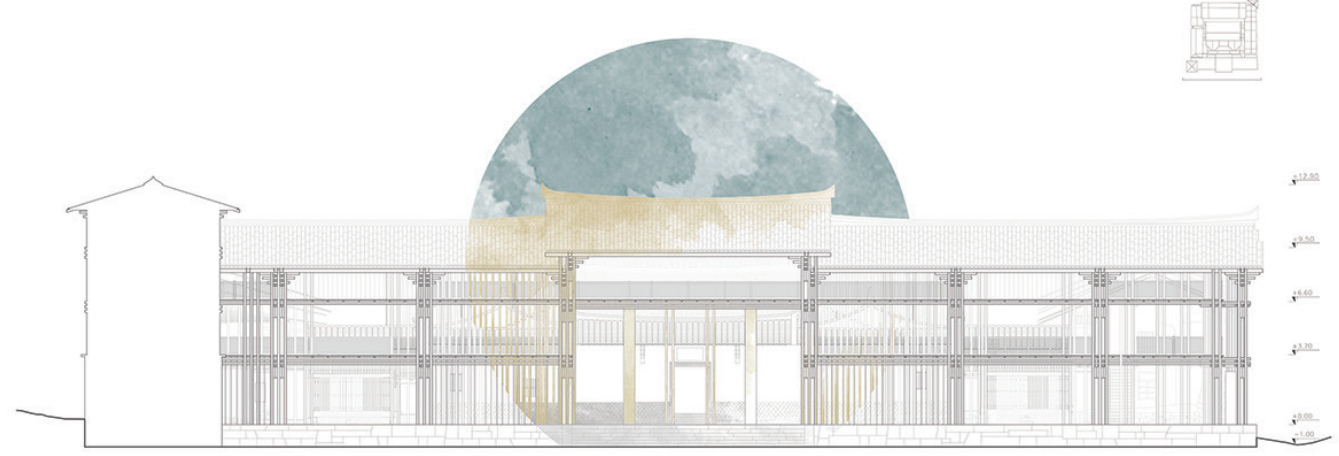




\section{La corte: progetto di ricomposizione delle forme dell'abitare}

La ricomposizione del versante est della fortificazione segue il principio cardine del progetto: restituire il carattere identitario e l'assetto originario del luogo da ri-abitare. Dallo studio planimetrico dell'area è emersa una regola precisa, un ritmo e una proporzione tra le parti, la cui modularità è il principio su cui si fonda il disegno dell'intero edificio. II prospetto principale è collocato sul lato più stretto, dove è presente l'accesso principale all'abitazione, generalmente posto a destra; un secondo ingresso sul prospetto posteriore, dà accesso all'area di pertinenza. L'ambiente interno è diviso da un tramezzo, cui è addossata una scala, unico collegamento con la zona notte al livello superiore; un ballatoio segna trasversalmente il prospetto, segnando la suddivisione in piani.

Da un'attenta analisi di forme e modi di abitare la ruralità in Cina, si è avviato il processo compositivo che ha considerato l'allineamento rispetto alle tracce della fortificazione esistente, lasciando immutati gli assi di percorrenza. Il progetto della nuova residenza, si articola su tre livelli: zona giorno, zona notte e sottotetto, la cui divisione dalle altre abitazioni è data unicamente da pilastrini di bambù. Uno spazio che offre ad ogni famiglia una propria area di pertinenza e gode di illuminazione naturale grazie alla copertura posta a due quote differenti. Attraverso ampie aperture, si traguarda la vallata costellata da risaie e diverse colture, e la foresta di bambù che lambisce il retro dell'edificio. Dai piccoli oggetti d'arredo ai collegamenti verticali, dalle mensole strutturali agli elementi portanti lasciati a vista, il bambù è declinato in tutte le sue potenzialità. La cinta fortificata ha la funzione di perimetrare l'area, a differenza del nuovo "muro abitato" che è parte integrante delle abitazioni. La torre posteriore, connessa al nuovo muro abitato, riacquista la sua funzione iniziale di collegamento tra i due livelli del zhuangzhai. (M.M.).

Fig. 7. Dettaglio di una porzione del grande muro fortificato in pietra e terra battuta (foto di $M$. Calia, marzo 2019).

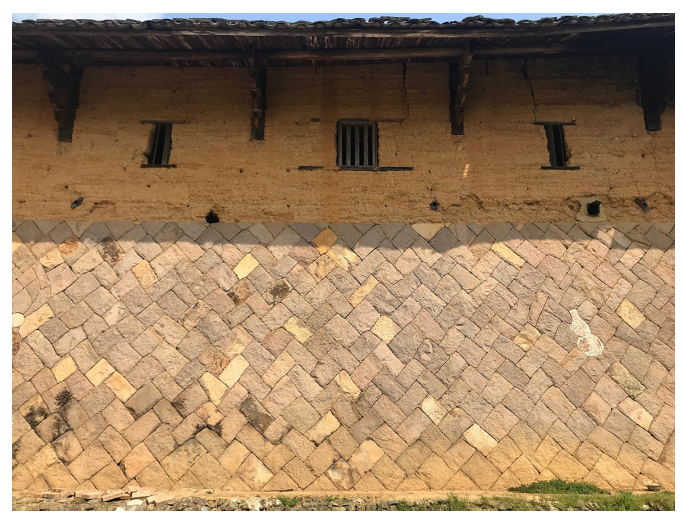

\section{La torre: caratteri difensivi e reinterpretazione tipo-morfologica}

La torre è una tipologia costruttiva che nella storia dell'architettura ha avuto particolare rilievo come elemento funzionale, di prestigio e difesa. In questo contesto si inserisce lo studio delle torri dei zhuangzhai, che ne sottolineano il carattere difensivo. Gli studi effettuati hanno portato ad una classificazione tipologica dei manufatti, che possono avere da una a quattro torri angolari o non presentarne nessuna. Si è rilevato che le torri poste sul retro hanno dimensione minore rispetto a quelle sul fronte principale. La spiegazione è dettata dalla presenza di un'altura retrostante come difesa naturale. Da questo studio tipo-morfologico, da ricostruzioni geometriche e da testimonianze bibliografiche riguardanti il caso studio Yue jiazhuang, che confermano la presenza di due torri in direzione N-O e S-E, è stato possibile stabilire la probabile posizione della torre demolita insieme al corpo frontale. Il progetto di ricostruzione è partito dallo studio dei rapporti originali di simmetria, ribaltando la torre del retro per risalire alla posizione, mentre lo studio dell'intera planimetria ha 
Fig. 8. Stralcio della pianta del primo piano del

completamento dell

recinto del Yue jiazhuan.

Fig. 9. Prospetto

dell'edificio residenziale

riprogettato a

mento della

parte posteriore del

recinto del Yue jiazhuang.

Fig. I0. Dettaglio

dell'attacco al cielo

del corpo residenziale

riprogettato

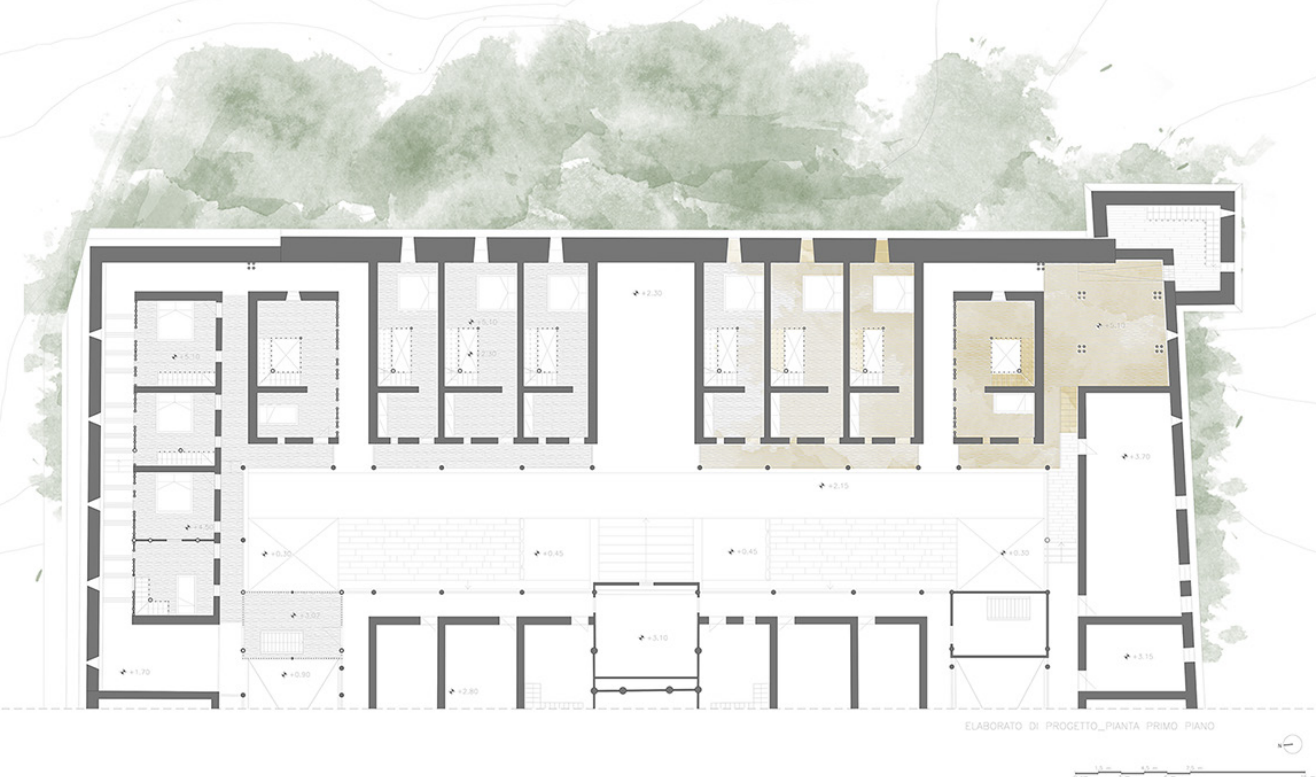

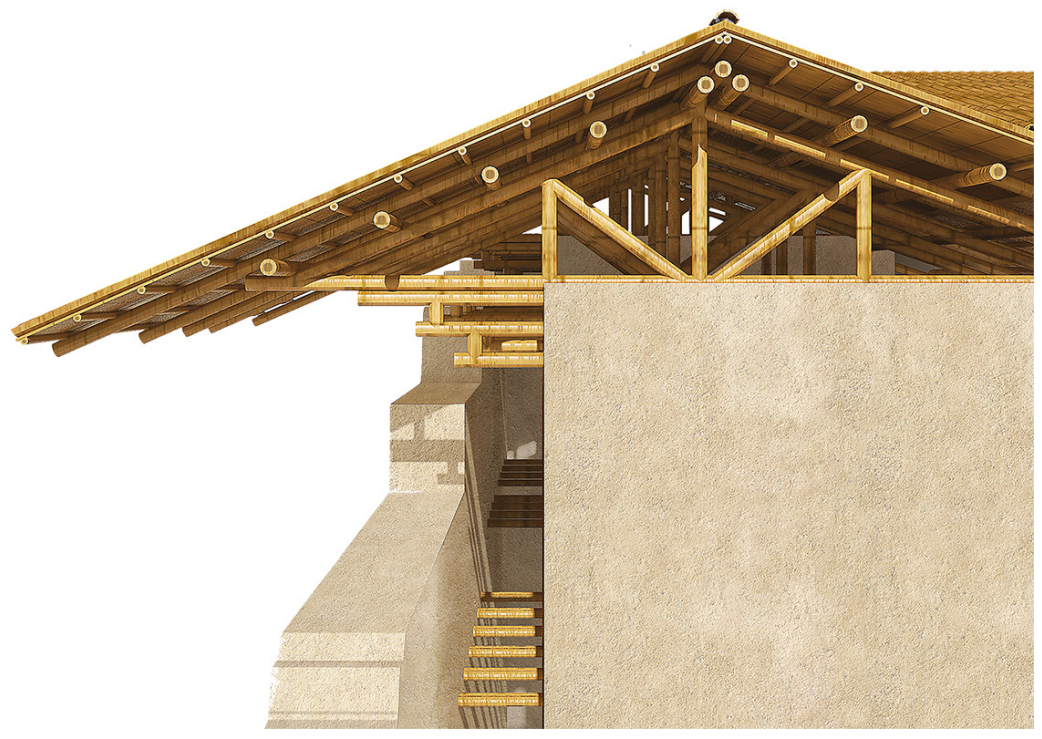


Fig. I I. Studio geometrico e proporzionale per ipotizzare la posizione della torre demolita sul
fronte principale del Yue jiazhuang.

Fig. 12.Vista prospettica esterna della torre riprogettata in pietra e bambù.
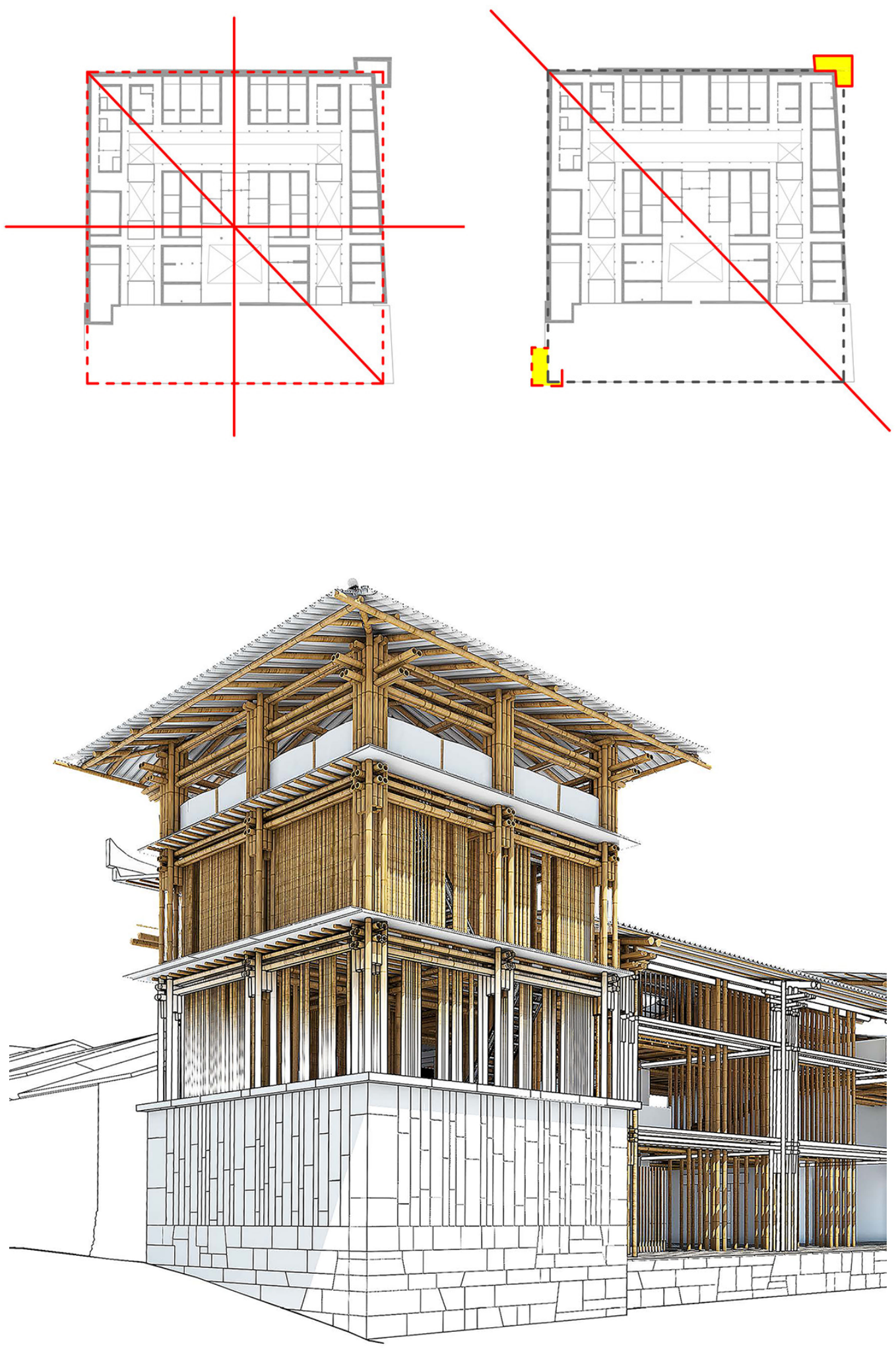
permesso di trovare un modulo comune a tutti gli spazi, giungendo così all'ipotesi planimetrica della nuova torre, con una pianta quasi perfettamente quadrata. Essa si eleva su tre piani e da un lato conserva le caratteristiche tipo-morfologiche di una "torre di avvistamento", mantenendo la chiusura e la massività del basamento in pietra, dall'altro si svuota e svetta con una struttura in bambù.

Il piano terra è uno spazio di accoglienza e il primo livello un accesso al corpo museale. Si accede al secondo livello tramite una scala in bambù che conserva l'idea della torre come spazio riservato. L'ultimo piano è una terrazza che si apre sul paesaggio. La torre come avvistamento diviene nuovamente prospettiva sul paesaggio rurale. (F.S.).

\section{Note}

[I] II workshop dal titolo: "Modelli di architetture contemporanee nei paesaggi scavati. Sostenibilità e innovazione tecnologica. Casi studio tra la Basilicata ed il sud della Cina", è stato organizzato nell'ambito del Laboratorio di Progettazione 5 "Architettura ed Eredità del Costruito" di cui è responsabile il Prof. Arch. Antonio Conte, all'interno del Corso di Studi in Architettura del DiCEM - UNIBAS a Matera.

\section{Riferimenti bibliografici}

AA. W. (20| 8). Fujian ZhuangZhai. Beijing: Beijing Normal University Publishing Group.

Calia Marianna (20 18). Taccuino Di viaggio. Dal sud della Cina a Guangzhou. Melfi: Libria.

Deqi Shan (2003). Chinese vernacular dwelling. Beijing: Beijing University Press.

Fanre David, Siu Helen (1995). Down to earth. The territorial band in South China. Stanford: Stanford University Press.

Li jianjun (20 I 8). Fujian Zhuangzhai. Hefei: Anhui University Press.

Zhang Binghua, Liu Shuhu, Li Jianjun, Chen Xiaohui (2019). The wisdom of the defensive Construction of Zhuangzhai in Eastern Fujian:The Case of Yongtai Zhuangzhai. In New Architecture, Issue I, pp. I 20- I 25.

\section{Autori}

Antonio Conte, Università della Basilicata, antonio.conte@unibas.it

Marianna Calia, Università della Basilicata, marianna.calia@unibas.it

Roberto Pedone, Università della Basilicata, roberto.pedone@unibas.it

Anna Lovino, Università della Basilicata, annalovino94@gmail.com

Mara Manicone, Università della Basilicata, maramanicone@gmail.com

Francesca Sbano, Università della Basilicata, sbanofrancesca@gmail.com

Per citare questo capitolo: Conte Antonio, Calia, Marianna Pedone Roberto, Lovino Anna, Manicone Mara, Sbano Francesca (2020). Ri-configurazione di parti ed elementi dell'architettura rurale: il recinto, la corte e la torre del Yue jiazhuang nel Fujian in Cina/Re-configuration of parts and elements of rural architecture: the fence, the court and the tower of Yue jiazhuang in Fujian, China. In Arena A., Arena M., Brandolino R.G." Colistra D., Ginex G., Mediati D., Nucifora S., Raffa P. (a cura di). Connettere. Un disegno per annodare e tessere. Atti del $42^{\circ}$ Convegno Internazionale dei Docenti delle Discipline della Rappresentazione/Connecting. Drawing for weaving relationships. Proceedings of the 42th International Conference of Representation Disciplines Teachers. Milano: FrancoAngeli, pp. $1099-1118$. 


\title{
Re-Configuration of Parts and Elements of Rural Architecture: the Fence, the Court and the Tower of Yue Jiazhuang in Fujian, China
}

\author{
Antonio Conte \\ Marianna Calia \\ Roberto Pedone \\ Anna Lovino \\ Mara Manicone \\ Francesca Sbano
}

Abstract

Beyond the megalopolises, the high technology that has invaded local communities, there is a China made of architecture immersed in the greenery of large rice fields, high mountains and extensive bamboo forests. An agricultural China made up of men who carry huge baskets of vegetables on narrow walkways in beaten earth, which preserve habits that have been handed down for centuries as rituals of ways of life and adaptation to the land.

This research work fits into this context, in continuity with the study trip made in March 2019, co-financed by the $\mathrm{MAECl}$ youth exchanges call, which allowed to deepen the knowledge and the study of fortifications in rammed earth typical of Fujian region.

Tulou, tubao and zhuangzhai: three types of housing settlements with common characters, each with its own history and construction tradition to be investigated and told. The surveys of five zhuangzhai located in Yongtai county led us to choose the case study: the Yue jiazhuang. The design experimentation focused on the knowledge, interpretation, reconstruction and restoration of some parts in ruins and some demolished, using tools and methods of architectural survey, also through advanced digital 3D technologies and drones, architectural composition, restoration and regeneration urban.

Keywords

rural landscapes, fortified architecture, twine, re-habit, zhuangzhai.

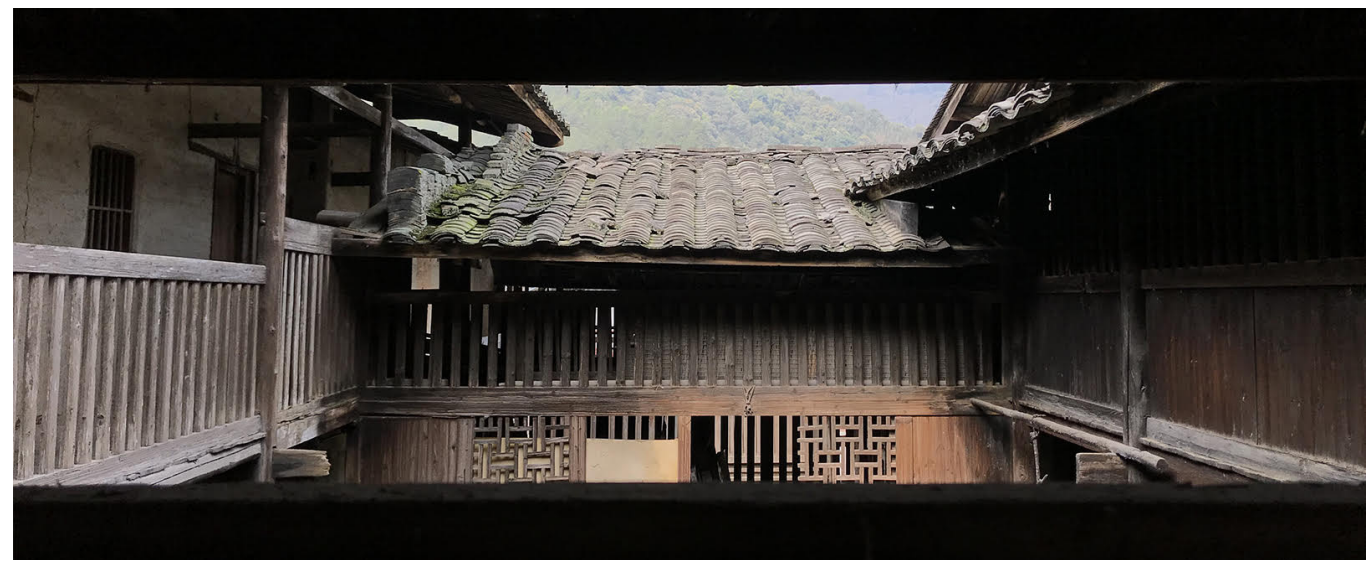




\section{Drawing, thinking, building in distant landscapes}

"Non ho scritto neppure la metà delle cose che ho visto" [Marco Polo, II Milione, 20I I, p. 48]

So, writes Marco Polo, the great traveler who first spread detailed writings and stories about Middle-Earth in the West. Many ethnic groups, languages, faces, customs and cultures: China is this and more. The only millennial empire in the history of humanity, once closed and self-referential, in recent decades it has found itself at the center of a significant evolutionary acceleration in all fields of the human being. But beyond the megalopolises, the high technology that has invaded local communities, there is a China made of architecture immersed in the greenery of large rice fields, high mountains and extensive bamboo forests. This research work fits in this context, in continuity with the study trip made in March 2019, which allowed to deepen the knowledge of the rammed earth fortifications, typical of the Fujian region, focusing on the project of new ways of 'Inhabit the Earth'.

Tulou, tubao and zhuangzhai: three types of settlements with common characters, each with its own history and construction tradition to be investigated and described. If the tulou, already inscribed in the UNESCO list since 2008, have already told their stories, tubao and zhuangzhai still remain little investigated. This research and design experimentation was substantiated with the participation in the workshop co-financed by $\mathrm{MAECl}$ for the 'Youth Exchange' call [I]. The project is articulated through the description of a broad path of knowledge, from the Dynasties that ruled the Country, to insights on traditional and rural Chinese architecture, to focus on the zhuangzhai of the Fujian region. The research work has developed, not only on the constructive principles of Chinese architecture, but also on the deep influences that symbols, beliefs and philosophies have had on it, from the precepts of feng shui architecture to its typologies, up to the insights on parts and construction elements of fortified rammed earth architecture.

The surveys on five zhuangzhai located in Yongtai County, led to the choice of the case study: the Yue jiazhuang. The design experimentation focused on the knowledge, interpretation, reconstruction and restoration of some parts in ruins and others demolished, using tools and methods of architectural survey, also using advanced digital3D technologies and

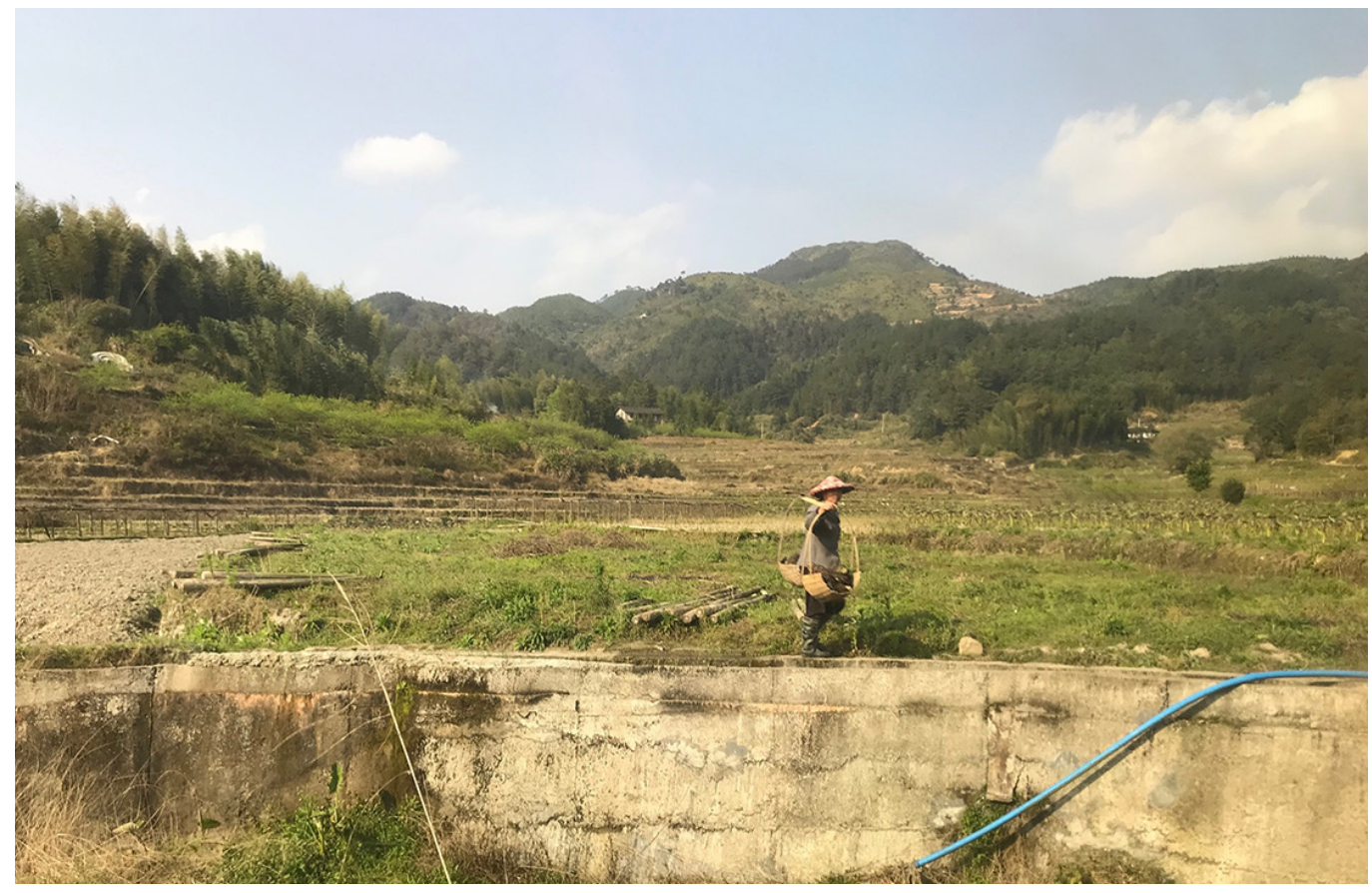


drones. Knowledge and Design have often overlapped in respect of local tradition, between the cultural approach of our education and that of types and models shared in the complex history of ways of inhabiting the Earth, which have gone through deeply different cultures. Understanding the archetypes, types and shapes, parts and elements, the human needs of the residents and of the territory and translating them into architecture, has turned into interpretative drawings of a way of life that represents a complex reality yet to be studied, enhanced and testify. The project, between analysis and representation, tried to give some answers for a concrete transformation hypothesis. In our path of understanding and appropriation of deeply different cultures, drawing, thinking and building in distant landscapes, fully represents, through the project, a testimony of the continuity of collective works of an ancient tradition in re-inhabiting the Earth. (A.C.).

\title{
Research tools and methods for knowledge of ancient heritages in Fujian
}

\author{
"Costruisci meglio che puoi. Ma non oltre le tue possibilità. \\ [... Fa' attenzione alle forme con cui costruisce il contadino, perché sono patrimonio tramandato della \\ saggezza dei padri. Cerca però di scoprire le ragioni che hanno portato a quella forma. \\ [...] Non temere di essere considerato poco moderno. I cambiamenti delle tecniche costruttive \\ tradizionali sono ammissibili solo quando comportano dei miglioramenti; \\ in caso contrario, mantieniti ancorato alla tradizione. \\ Perché la verità, anche se vecchia di centinaia di anni, \\ ha con noi un legame interno più forte della menzogna che ci cammina accanto"
} [Loos Adolf, Parole nel vuoto, 1992 p. 27]

The approach to the knowledge of places faraway, with characters that are deeply different from those we are used to face ourselves every day, can frighten but also fascinate to the point of pushing a group of students and researchers to develop a project of research and design experimentation, complex and articulated.

International relations of the University of Basilicata, built with passion and determination since 2009, have found in Fuzhou University a decisive partner, available to share research lines around issues of protection and enhancement of architectural and landscape heritage. The interest in the systems of 'earth architecture', expertly built over the centuries through the consolidation of construction traditions, the use of local materials and composition of the spaces, has matured thanks to the support of the colleagues of the FZU and to the intense study visits and surveys.

The zhuangzhai belong to one of the types of fortified architecture found in the extensive rural areas of Fujian region, southeastern coast of China.The choice to investigate their characters and identity is motivated by the lack of information and scientific studies on them.

Within the broad classification of 'Fujian earth architecture', we can also mention the tulou, large collective residences with clear symbolic characters, the tubao, temporary fortified shelters, which represent man's attempt to build in close relationship with earth morphology and the weilongwu serial housing aggregates, built by Hakka ethnic groups mainly in Guangdong region.

Considering a careful knowledge activity and approach to the millennial Chinese culture through Architecture tools, substantiated with restitution of surveys carried out on site and drawings of analytical synthesis, this work has meticulously and critically translated into design thinking, a work shared with teachers and researchers from the two Countries, involved in the different on-site survey phases and in the design laboratory and didactic experimentation.

The objective that this work proposes is to connect and promote the knowledge of these earthen architectures within the international scientific community, providing a personal and critical contribution to their contemporary protection and sustainable regeneration, also in support of a possible participation in the candidacy of the zhuangzhai as World Heritage Site (M.C.). 


\section{Observation, a critical phenomenon of prefiguration to the new form}

Investigating such a complex structure through the recognition of its modularity, the composition of the parts, the intertwining and the joints, required a constant direct and descriptive visual approach.

The zhuangzhai is a rural building with great landscape value, whose strong bond with the land is evident where its inhabitants intimately participate in the harvest cycles. You can read traces of the myths between religion and local building culture, through the rational partition of the rooms, the circle, the abstraction of the celestial vault and the square, the base, the attack on the ground and on earthly life, everything merges, returning a golden aura of sacredness legible in the black paintings on a red background that cover the wooden supports of the central courtyard.

In the joints of the wooden structures, distant knowledge and manual technique are knotted, through horizontal and vertical grafts and the terminals resting on shaped and carved stone blocks with repeated geometric designs. In this detail, we find one of the main rules of construction, the relationship between water and building: detach the wooden support from the ground to avoid the priming of the water and its slow and inexorable deterioration. It is evident that architectural synthesis has responded to this problem in two ways: technical and aesthetic instances in finely executed original solutions.

In this framework, one of the possible routes is followed: the desire to restore the foundational aspect of the building which has been deprived of important testimonial parts such as the corner tower, the entrance front and the rear closure. The ordering choice of the intervention was the integral recomposition of the image of the zhuangzhai, which took place through the study of architectural gaps with the aim of restoring unity to the organism. Once the objectives of the experimental project were identified, the reconstruction took place by modulating a sustainable local material such as bamboo, through the juxtaposition of elements designed in detail and related to the context. (R.P.).
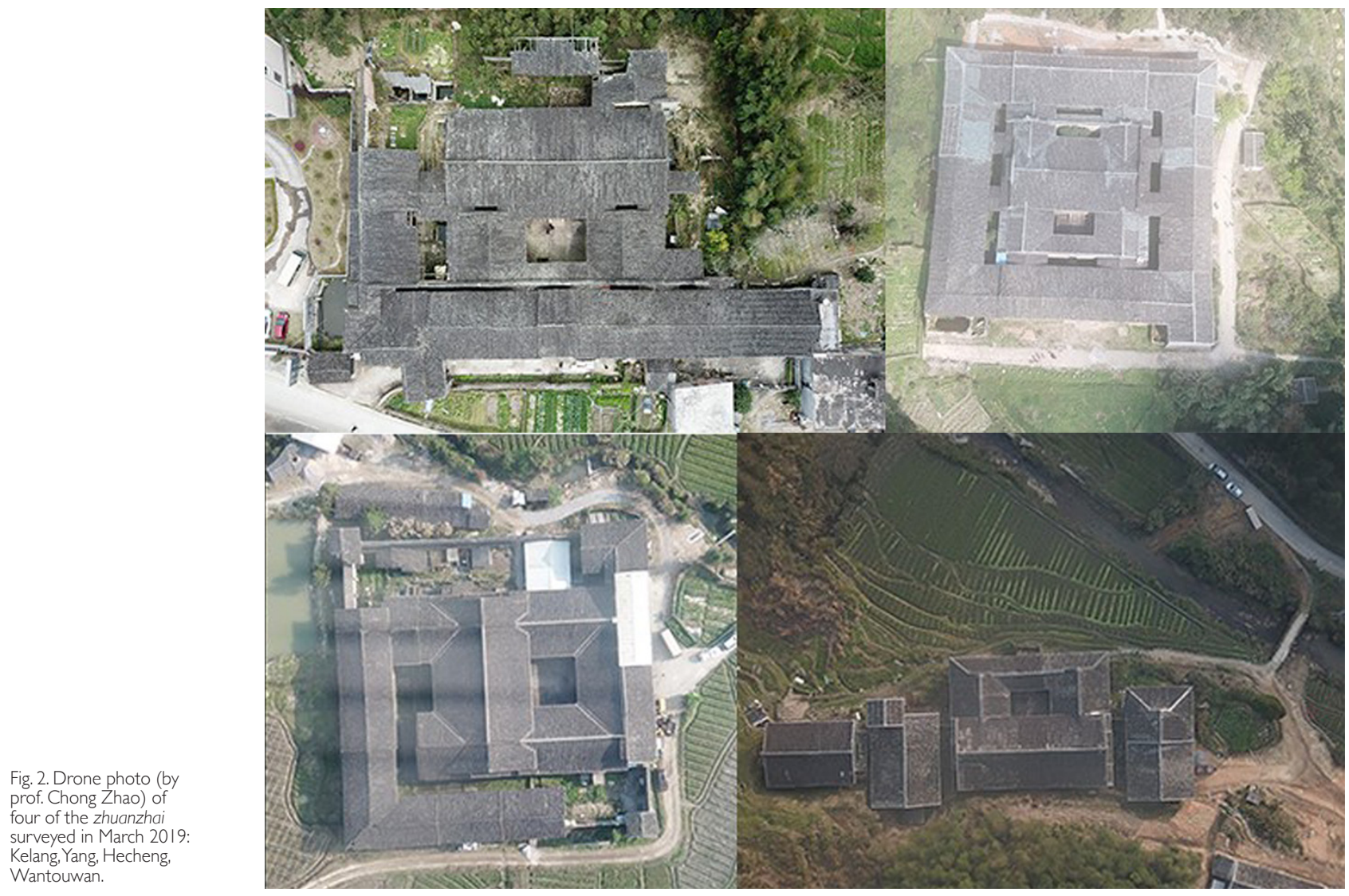


\section{The fence: reconstruction and reinterpretation on the traces of the demolished front}

In 1970 in Ling Xiao village, practical and political needs, prevailing over cultural and aesthetic ones, caused substantial changes to the rural context and to the unitary image of the Yue jiazhuang. By demolishing the main front and one of the corner towers, the integrity of the building was compromised, changing its appearance and giving up the geometric principles of symmetry. What remains is an incomplete and vulnerable architecture, which needs a new face to relate nature and construction.

Fig. 3. Front view of the distribution galleries (photo by M. Calia, March 2019).

Fig. 4.View of the interna service courtyard, in crossings, distribution by galleries and water collection are evident (photo by M. Calia, March 2019).

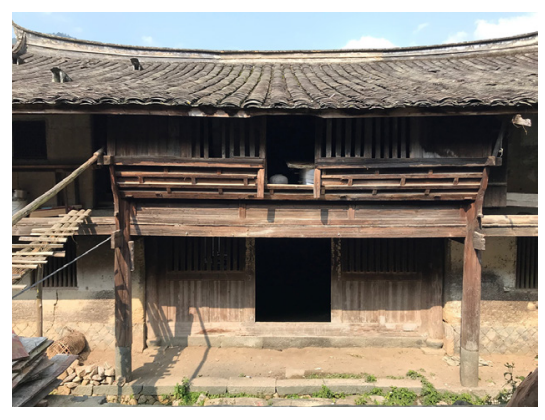

The solution was highlighted by the same context and by the dense bamboo plantations that inspired the idea of infusing the same modular scan into an architectural rhythm. Alternation between full and empty, which brings us closer to the denser space, typical of the interior of the fortification. The architectural space becomes a historical narrative, capable of letting myths, traditions and constructive solidity shine through, while leaving traces of what it was. The project intends to complete the building in the form by proposing an integration of the gap, which is measured with the surrounding environment and proposes its modularity. This empirical rule, readable by the mesh deduced from the partitions and openings of the building, allowed to find the internal distribution of the project and determined the position of the bamboo pillars of the facade articulated on three levels: the ground floor is a symbolic space characterized from the verticality of the pillars. The shadows draw horizontally what the material expresses vertically, lead to the imposing portals, directing the gaze towards the warm color of the clay walls with the traces of the demolitions. The first and second floors are narrative places, a museum in the making that enhances painting and calligraphy in the most reserved place of the building: the tower.

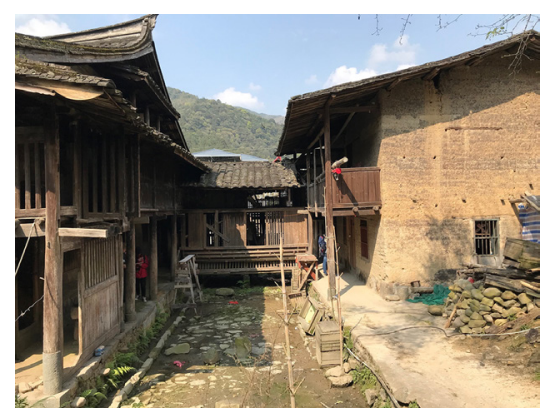

The suggestion is accentuated by the view on the landscape, a new observation point from which to see the village in its entirety, a detail that represents the 'door of the monument'. The space from which it is possible to appreciate the characters of the entire zhuangzhai is the second floor, an environment that recalls the restricted space of the attic of rural buildings, punctuated by the pillars that support the roof and by dense shields that cut out the scenery in suggestive shots. The frame of this figuration is the imposing bamboo roof, which reinterprets, overlooks and protects the newly found domesticity. (A.L.). 
Fig. 5. Comparison between the drone photo and the design of the reorganization project of the demolished front and rearrangement of the area in front of

Fig. 6. Redesigned front façade of the Yue jiazhuang.
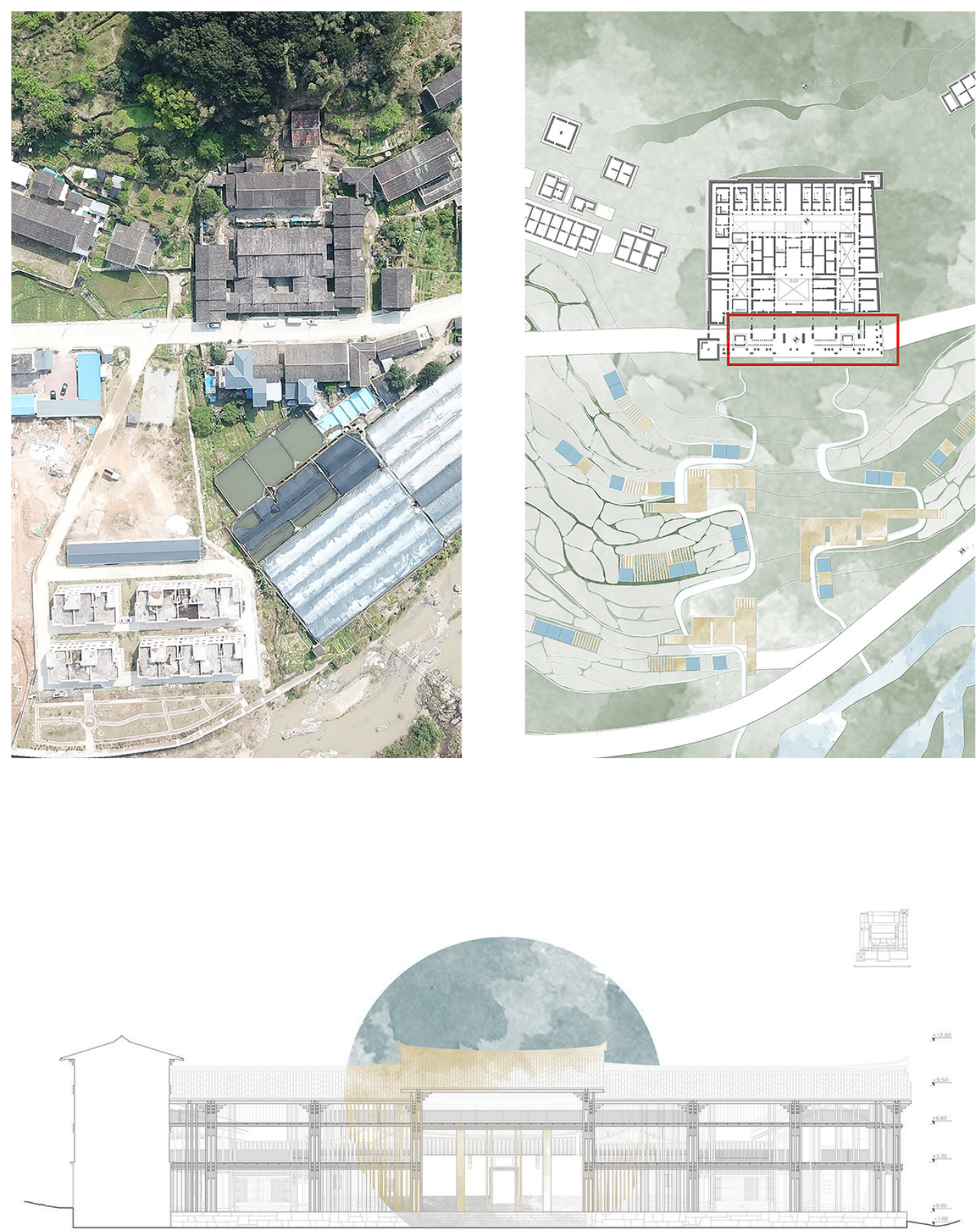


\section{The courtyard: project of recomposition of the forms of living}

The re-composition of the eastern side of the fortification follows the cardinal principle of the project: to restore the identity and the original structure of the place to be re-inhabited. The plan metric study of the area revealed a precise rule, a rhythm and a proportion between the parts, whose modularity is the principle on which the design of the entire building is based. The main façade is located on the narrowest side, where there is the main access to the house, generally located on the right; a second entrance on the back façade gives access to the private area. The internal environment is divided by a partition wall, which is supported by a staircase, the only connection to the sleeping area on the upper level; a balcony marks the elevation transversely, marking the division into floors.

From a careful analysis of forms and ways of inhabiting rurality in China, the compositional process was started which considered the alignment with respect to the traces of the existing fortification, leaving the walking axes unchanged. The project of the new residence is divided into three levels: living area, sleeping area and attic, whose division from the other houses is given only by bamboo pillars. A space that offers to each family its own area and enjoys natural lighting thanks to the roofs located at two different heights. Through large windows, you can reach the valley dotted with rice fields and various crops, and the bamboo forest that laps the back of the building. From small furniture items to vertical connections, from structural shelves to load-bearing elements left exposed, bamboo is declined in all its potential. The fortified wall has the function of surrounding the area, unlike the new 'inhabited wall' which is an integral part of the houses. The rear tower, connected to the new inhabited wall, regains its initial function of connection between the two levels of the zhuangzhai. (M.M.).

Fig. 7. Detail of a portion of the large fortified wall made of stone and

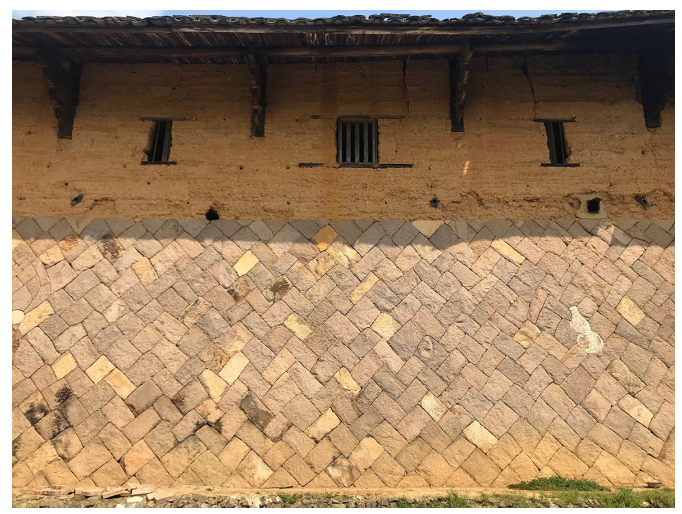

\section{The tower: defensive characters and type-morphological reinterpretation}

The tower is a construction type that in the history of architecture has had particular importance as functional, prestigious and defensive element. In this context, the study of the towers of the zhuangzhai fits, which underline their defensive character. The studies carried out have led to a typological classification of the artefacts, which can have from one to four corner towers or have none. The towers on the back have been found to be smaller in size than those on the main front. The explanation is dictated by the presence of a hill behind it as a natural defense. From this morphological-type study, from geometric reconstructions and bibliographical testimonies concerning the Yue jiazhuang case study, which confirm the presence of two towers in the $\mathrm{N}-\mathrm{O}$ and $\mathrm{S}-\mathrm{E}$ direction, it was possible to establish the probable position of the demolished tower together with the frontal body.

The reconstruction project started from the study of the original symmetry ratios, overturning the tower of the back to go back to the position, while the study of the entire plan 
Fig. 8. Part of the plant extract of the first floor with the completion of the back fence of the Yue jiazhuang.

Fig. 9. Façade of the

residential building

to complete

the back fence of the Yue

jiazhuang.
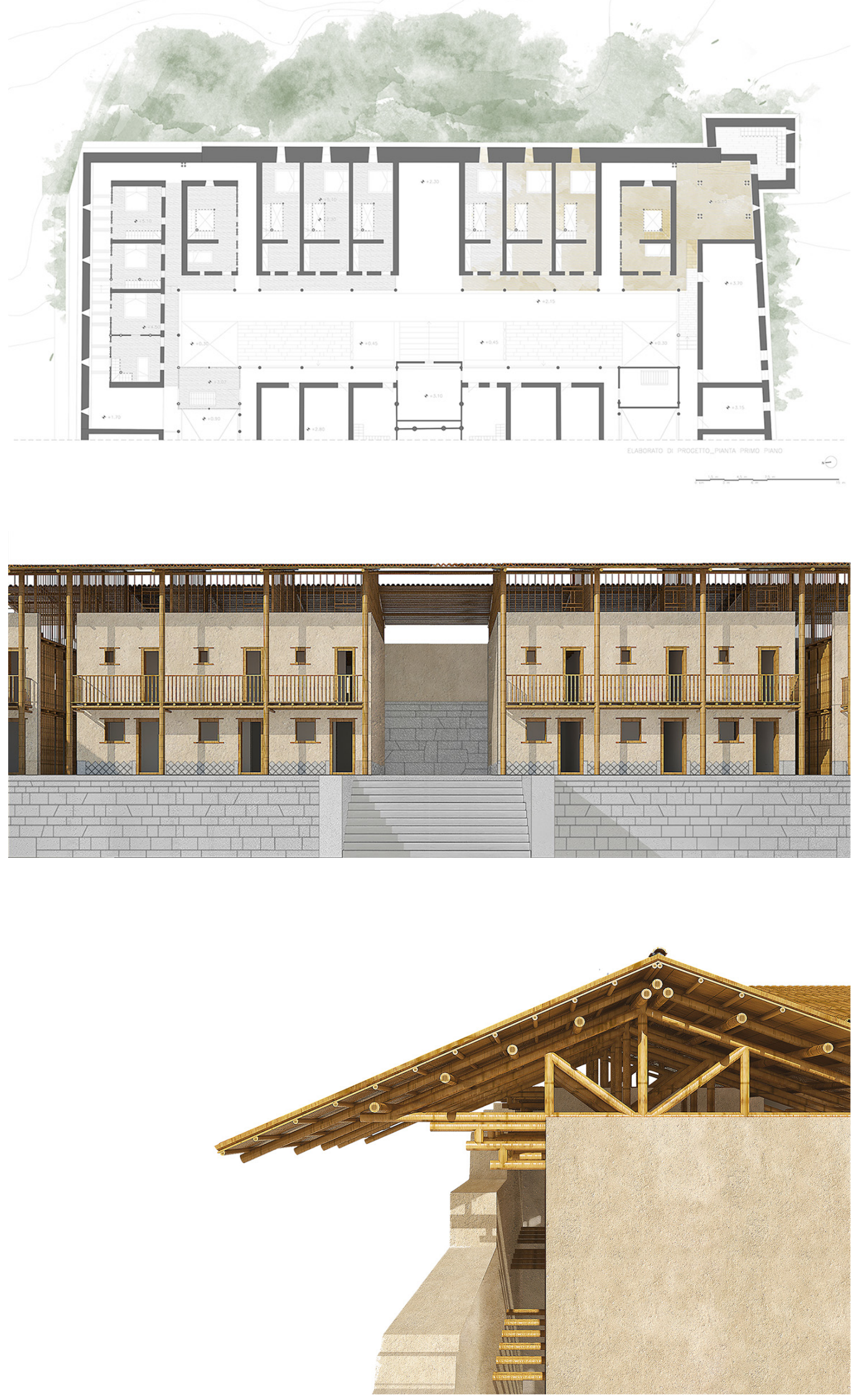
Fig. I I. Geometric and proportional study to hypothesize the position of the demolished towe Yue jiazhuang.
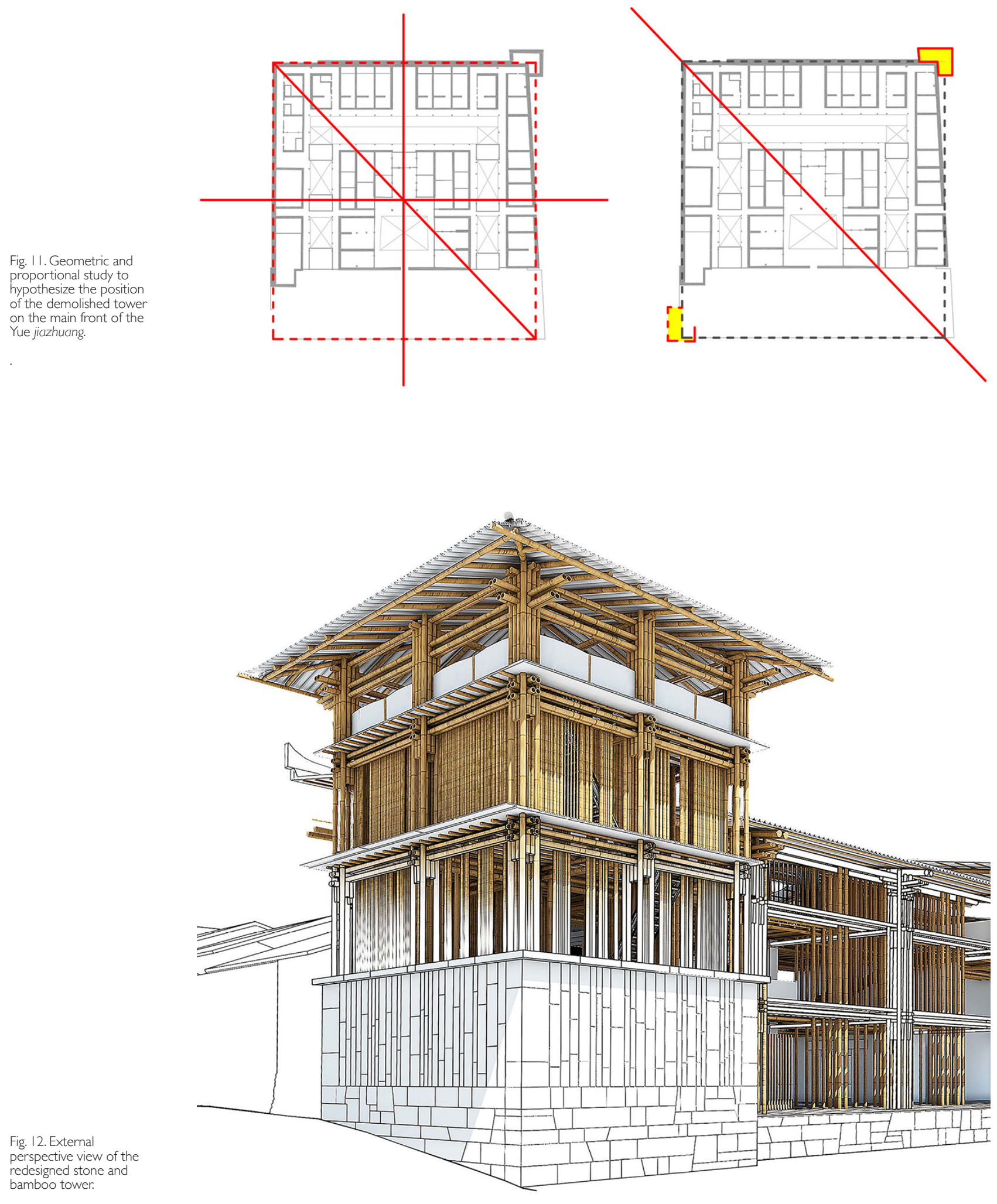

Fig. 12. External perspective view of the redesigned ston
bamboo tower 
allowed to find a module common to all spaces, thus reaching the plan metric hypothesis of the new tower, with an almost perfectly square plan. It rises on three floors and on one side retains the type-morphological characteristics of a 'watchtower', maintaining the closure and the massiveness of the stone base, on the other it empties and stands out with a bamboo structure.

The ground floor is a welcoming space and the first level an access to the museum. The second level is accessed by a bamboo staircase which preserves the idea of the tower as a reserved space. The top floor is a terrace that opens onto the landscape. The tower as a sighting becomes again perspective on the rural landscape. (F.S.).

\section{Notes}

[I] The workshop named: Models of contemporary architecture in carved landscapes. Sustainability and technological innovation. Case studies between Basilicata and southern China, was organized in the framework of the Design Laboratory 5 Architecture and Heritage of the Building, managing by Prof. Arch. Antonio Conte, within the Architecture Degree course at DiCEM - UNIBAS, Matera.

\section{References}

AA.W. (20 I8). Fujian ZhuangZhai. Beijing: Beijing Normal University Publishing Group.

Calia Marianna (2018). Taccuino Di viaggio. Dal sud della Cina a Guangzhou. Melfi: Libria.

Deqi Shan (2003). Chinese vernacular dwelling. Beijing: Beijing University Press.

Fanre David, Siu Helen (1995). Down to earth. The territorial band in South China. Stanford: Stanford University Press.

Li Jianjun (2018). Fujian Zhuangzhai. Hefei: Anhui University Press.

Zhang Binghua, Liu Shuhu, Li Jianjun, Chen Xiaohui (2019). The wisdom of the defensive Construction of Zhuangzhai in Eastern Fujian:The Case of Yongtai Zhuangzhai. In New Architecture, Issue I, pp. I20- I 25

\footnotetext{
Authors

Antonio Conte, Università della Basilicata, antonio.conte@unibas.it

Marianna Calia, Università della Basilicata, marianna.calia@unibas.it

Roberto Pedone, Università della Basilicata, roberto.pedone@unibas.it

Anna Lovino, Università della Basilicata, annalovino94@gmail.com

Mara Manicone, Università della Basilicata, maramanicone@gmail.com

Francesca Sbano, Università della Basilicata, sbanofrancesca@gmail.com
}

To cite this chapter. Conte Antonio, Calia, Marianna Pedone Roberto, Lovino Anna, Manicone Mara, Sbano Francesca (2020). Ri-configurazione di parti ed elementi dell'architettura rurale: il recinto, la corte e la torre delYue jiazhuang nel Fujian in Cina/Re-configuration of parts and elements of rural architecture: the fence, the court and the tower of Yue jiazhuang in Fujian, China. In Arena A., Arena M., Brandolino R.G., Colistra D. Ginex G., Mediati D., Nucifora S., Raffa P. (a cura di). Connettere. Un disegno per annodare e tessere.Atti del $42^{\circ}$ Convegno Internazionale dei Docenti delle Discipline della Rappresentazione/Connecting. Drawing for weaving relationships. Proceedings of the 42th International Conference of Representation Disciplines Teachers. Milano: FrancoAngeli, pp. I099- | I 8. 